International Journal of Current Microbiology and Applied Sciences

ISSN: 2319-7706 Volume 10 Number 10 (2021)

Journal homepage: http://www.ijcmas.com

\title{
Isolation and Biochemical Characterization of Lactic Acid Bacteria from Fermented Foods
}

\author{
A. Sirisha ${ }^{1 *}$, J. Lakshmi ${ }^{1}$, K. Lakshmi ${ }^{1}$ and A. Vijaya Gopal ${ }^{2}$ \\ ${ }^{1}$ Department of Foods and Nutrition, College of Community Science, \\ ${ }^{2}$ Department of Agricultural Microbiology, Advanced Post Graduate Centre, Acharya N.G. \\ Ranga Agricultural University, Lam, Guntur, Andhra Pradesh, India \\ *Corresponding author
}

\begin{tabular}{l} 
Key w o r d s \\
$\begin{array}{l}\text { Fermentation, } \\
\text { isolation, } \\
\text { biochemical } \\
\text { characteristics, } \\
\text { Lactobacillus }\end{array}$ \\
\hline Article Info \\
\hline $\begin{array}{l}\text { Accepted: } \\
\text { 15 September } 2021 \\
\text { Available Online: } \\
\text { 10 October } 2021\end{array}$ \\
\hline
\end{tabular}

A B S T R A C T
Probiotics are considered as successful major category of food supplements. Probiotics can be functional foods because their health benefits are essentially higher than traditional nutritional products. Probiotic bacteria was collected from home made and commercial fermented food samples. A total of 30 food samples were collected from local areas of Guntur in Andhra Pradesh. Bacteria were isolated on MRS agar medium after observation of growth and pure culture was obtained by sub-culturing on the same medium. Purity of each culture was confirmed by morphological investigation, Gram's staining and further identification by specific biochemical tests. The isolates from both dairy and non-dairy fermented foods were identified as rods, bacilli, cocci and chain shape. While some isolates showed positive results some showed negative results for catalase test, methyl red test, oxidase test, aescualin fermentation, starch hydrolysis, arginine hydrolysis, citrate utilization and voges prausker's test reaction. Based on morphological, cultural and biochemical characterization of 16 bacterial isolates out of 30 were identified as Lactobacillus spp.

\section{Introduction}

Microorganisms which have specific favorable effects on humans and animals are used as probiotics. Those organisms provide not only gut flora balance but also maintain good health condition (Schrezenmeir and Verse,
2001). The probiotic bacteria are Bifidobacterium Enterococcus, Lactobacillus and Streptococcus species. These bacteria play an extensive role in contrary to harmful microorganisms and strengthen the host's immune system (Soccol et al., 2010). "Living microorganisms" are probiotics that provide 
the host with health benefits when administered in sufficient quantities. Probiotics must meet certain key criteria such as tolerance to the intestine $\mathrm{pH}$ and bile salts, sensitivity to antibiotics and inhibition of growth in other harmful organisms. A huge number of microbes present in human intestine forms a wide range of health-active molecules. Diet and functional foods are essential modulators for gut microbiotas to improve the health of the hosts (Johan et al., 2011).

In present conditions probiotics are being used worldwide as a major predominant category of food supplement. Probiotics can be functional food because their health benefits are significantly higher than the traditional food products. Several studies reported that probiotics can succeed in different types of infectious diseases, colon cancer, immune modulations and other chronic gastrointestinal inflammatory disorders as evidenced by highquality scientifically based clinical information. Antimicrobial products of probiotic bacteria produce bacteriocins which are used against food spoiling organisms and to raise safety of foods (Nout,2014). During the process of fermentation, the microorganism's breakdown carbohydrates into carbon dioxide, organic acid and alcohol (Ansorena and Astisaran, 2016). Lactic acid bacteria (LAB) indicated as gram positive non-motile, non-sporulating bacteria produce more amount of lactic acid during fermentation process (Pelinescu et al., 2009).

These are generally considered safe and suitable for medical applications (Hoque et al., 2010). They have rod- or coccus-shaped cells (Zhang et al., 2014) and are microaerophilic or anaerobic and acid-tolerant organisms (Shaukat, 2020).LAB initiates speedy and tolerable acidification of raw materials by producing different organic acids derived from carbohydrates. LAB is capable of producing lactic acid, bacteriocin, ethanol, exopolysaccharides, certain enzymes and flavouring compounds (De Vuyst \& Leroy, 2007).

LAB has a prolonged history in cheese processing and consumption. Due to its organoleptic properties, the fermented food is more popular than unfermented foods among consumers. Due to the acid production, LAB reduces $\mathrm{pH}$ below $4{ }^{\circ} \mathrm{C}$ and hinders pathogenic development. These pathogenic microbes spoil milk and cause diseases (Ananou et al., 2007). Lactobacilli as beginners for fermented vegetables, milk products and sausages as well as inoculants are being used for food preservation. Lactobacilli are also proposed for the production of nutraceuticals (Widyastuti et al., 2010).

More studies and considerable evidence that probiotics have an influence on several aspects of innate and acute immunity through $\operatorname{IgA}$ secretion and phagocytosis, which include alteration in T-cell responses, improvement in Th1 responses and attenuation of Th2 responses (Guarner et al., 2003).

Prebiotics can be used to supplement probiotic products. It turns out that developing biological therapeutic formulas containing microbial and synergistic strains in both the colon and the intestine can lead to a more pronounced probiotic effect. These enhanced products may be more effective and have a greater protective and stimulating effect than their individual components (Bomba et al., 2002).

\section{Materials and Methods}

\section{Sample collection}

Initially market survey was done for identification of commercially available foods in the local markets and also identified 
homemade cultured or fermented products. 30 samples were collected for the study through random sampling method. Samples of commercially available probiotic foods taken from different local markets and some of cultured samples collected from households in Guntur.

\section{Isolation of probiotic bacterial isolates}

Serial dilution and pour plate technique were followed. Ten $\mathrm{ml}$ of the sample in $90 \mathrm{ml}$ sterile water blank for liquid samples and tengram sample in case of solid samples in 100 $\mathrm{ml}$ sterile water blanks were mixed thoroughly and serially diluted up to $10^{5}$ dilutions. From $10^{2}$ and $10^{3}, 10^{4}$ one $\mathrm{ml}$ each diluent was transferred to sterile Petri dishes and the molten and cooled MRS medium was poured after solidification. The plates were incubated in an inverted position for $24-48 \mathrm{hrs}$ at $30^{\circ} \mathrm{C}$. The characteristic LAB colonies growing over the incubated plates were picked up carefully and streaked on the MRS agar medium for further purification. The discrete single colonies were picked up and inoculated into MRS broth in the culture vials and the grownout cultures were maintained at $4^{\circ} \mathrm{C}$ in a refrigerator for further studies. The isolates were assigned the code numbers (Awan and Rahman, 2005).

\section{Enumeration of isolates}

$10 \mathrm{~g}$ of each food sample was taken in $250 \mathrm{ml}$ conical flask to which $90 \mathrm{ml}$ of sterile saline was added aseptically. The sample was agitated for 15 minutes on cyclomixer and serial dilutions of samples were prepared. $1 \mathrm{ml}$ of respective dilutions were poured in to the sterile petriplates followed by MRS Agar medium. Then the petri plates were incubated at room temperatures for 24-72 hrs in a bacteriological incubator. After incubation colonies formed and population was expressed as $\mathrm{CFU} x$ dilution factor $\mathrm{g}-1$ of sample.

\section{Colony characteristics}

The morphological characteristics of the colony of each isolate were examined on MRS agar medium by incubating for specific period. Cultural characterization of isolates such as shape and stain reaction were recorded (Aneja, 2003).

\section{Gram staining}

A loop full of inoculum from young culture was taken and mixed with a drop of sterile distilled water placed in the center of the slide. The suspension was spread out on slide using the tip of inoculation needle to make a thin suspension.

The smear was dried in air and fixed through mild heating by passing the lower side of the slide three to four times over the flame. Then each smear was covered with crystal violet for 30 seconds followed by washing each slide with distilled water for few seconds.

Then each slide was covered with Gram's iodine solution for 60 seconds, then washed with $95 \%$ ethyl alcohol followed with distilled water and drained. The bacteria that appeared purple were referred to as Gram-positive and those that were pink as Gram-negative (Aneja, 2003).

\section{Bio chemical characterization of effective isolates}

\section{Catalase test}

Catalase test was conducted by dripping two drops of hydrogen peroxide $\%$ at 24 hours aged cultures on an object glass slide. Catalase test positive reaction characterized by the formation of oxygen bubbles that indicate the bacteria produce the catalase enzyme which converts $\mathrm{H}_{2} \mathrm{O}_{2}$ to water $\left(\mathrm{H}_{2} \mathrm{O}\right)$ and oxygen $\left(\mathrm{O}_{2}\right)$ (Rangaswamy and Bagyaraj,1993). 


\section{Oxidase test}

The overnight cultures of the test isolate were spotted on plates poured with sterile trypticase soya agar (TSA) and the plates were incubated for 24 hours at $30^{\circ} \mathrm{C}$.

After incubation, oxidase discs placed in the petri plates on the growth of culture within few minutes turns into blue colour indicates positive. No colour change indicates negative (Ifeanyi et al., 2019).

\section{Methyl red test}

Sterilized glucose-phosphate broth tubes were inoculated with the test culture and incubated at $30^{\circ} \mathrm{C}$ for 48 hours. After incubation five drops of methyl red indicator were added to each tube and gently shaken. Red colour production was taken as positive and yellow colour production was taken as negative for the test (Crown and Gen,1998).

\section{Voges Proskauer's Test}

To the pre-sterilized glucose-phosphate broth tubes, test cultures were inoculated and incubated at $37^{\circ} \mathrm{C}$ for $48 \mathrm{hrs}$.

After incubation ten drops of Barrit's reagentA was added and gently shaken followed by the addition of Barrit's reagent- $B$. The development of pink colour in the broth was taken as positive for the test (Faddin, 2000).

\section{Gas from Glucose}

Sterile test tubes of $10 \mathrm{ml}$ glucose broth containing Durham's tube (inverted and dipped), were inoculated with Lactobacilli cultures at the $1 \%$ and incubated at $37^{\circ} \mathrm{C}$ for 24-48 $\mathrm{h}$. Gas production that appeared in the form of a hollow space in Durham's tube was recorded as a positive result (Monica et al., 2012).

\section{Arginine Hydrolysis}

Production of ammonia from arginine was tested by inoculation of the isolates in arginine broth. After $24 \mathrm{~h}$ of incubation, $100 \mu \mathrm{l}$ of the sample was spotted on white tile and equal volume of Nessler's reagent was added.

Immediate appearance of dark orange color indicates the presence of ammonia due to hydrolysis of arginine (Ghosh et al., 2011).

\section{Aescualin fermentation}

The isolates were also assessed for their ability to hydrolyze glycoside aesculin to aesculetin and glucose. For this, bile aesculin agar plates were streaked with the isolated cultures and incubated at $37{ }^{\circ} \mathrm{C}$ for $24-48 \mathrm{~h}$. After incubation, the plates were examined for the presence of a dark brown to black halo around the bacterial growth, showing a positive result for aesculin hydrolysis (Monica et al., 2012).

\section{Nitrate Reduction Test}

Nitrate reduction is an important criterion for differentiating and characterizing different types of bacteria. Therefore, the isolates were incubated at $37^{\circ} \mathrm{C}$ for $24 \mathrm{~h}$ in trypticase nitrate broth. After incubation, $0.5 \mathrm{~mL}$ each of sulphanilic acid $(0.8 \%$, in $5 \mathrm{~N}$ Acetic acid) and $\alpha$-naphthylamine $(0.5 \%$, in $5 \mathrm{~N}$ Acetic acid) were added into the tubes. The appearance of red or pink color indicated the positive test for nitrate reduction (Monica et al., 2012).

\section{Citrate Utilization Test}

The isolates were inoculated in Simmons citrate agar incubated at $37^{\circ} \mathrm{C}$ for $24 \mathrm{~h}$. After incubation, the appearance of blue coloration indicated the positive test for citrate utilization and was recorded accordingly for the isolates tested (Faddin, 2000). 


\section{Starch Hydrolysis}

Starch is a branched polysaccharide, used as a source of carbohydrate by certain bacteria. The starch containing medium is prepared by autoclaving at $121^{\circ} \mathrm{C}$ for $15 \mathrm{~min}$, poured onto the petri plates, allowed to dry and the isolates were streaked.

The plates were incubated for the period of 24 to $48 \mathrm{~h}$ at $37^{\circ} \mathrm{C}$. Iodine was added to the plate and incubated for $5 \mathrm{~min}$ to check for hydrolysis. Iodine forms complex with starch changing the background to blue - black. If starch is hydrolyzed, a clear zone was formed surrounding bacterial growth and if no hydrolysis the agar remained blue black with any clearance of the zone (Faddin, 2000).

\section{Results and Discussion}

\section{Collection of fermented foods}

The details regarding to collected samples from different local super markets, online sources and households in Guntur district of Andhra Pradesh.

\section{Collection of fermented foods from commercial sources}

The information related to collection of fermented foods from commercial sources is presented in Table 1

\section{Collection of fermented foods from house holds}

The information related to collection of fermented foods from households of Guntur is presented in Table 2.

Food samples like Home made curd (HCU), Dosa (DA), Dosa batter (DB), Idly (ID), Idly batter (IB), Punugu (PN) were the samples collected from households.

\section{Isolation and population of LAB}

The details of results pertaining to isolation and population of LAB from commercial and homemade fermented food samples are discussed here under Thirty fermented food samples were collected from various markets and households in Guntur and LAB were isolated on MRS (Mann, Rogosa, and Sharpe's agar) medium.

Sixteen of the thirty samples were tested positive for LAB population. The LAB population in fermented food products ranged from 1.5 to $10 \times 10^{4}$ (Table 4.5). Jersey Butter Milk had the maximum LAB population (10 x $10^{4} \mathrm{CFU} / \mathrm{ml}$ ), followed by Amul Butter Milk $\left(9.8 \times 10^{4}\right)$, Kombucha $\left(8.8 \times 10^{4} \mathrm{CFU} / \mathrm{ml}\right)$, Health Potion Drink $\left(7.2 \times 10^{4} \mathrm{CFU} / \mathrm{ml}\right)$, Mozzarella Cheese $\left(6.0 \times 10^{4} \mathrm{CFU} / \mathrm{ml}\right)$, Milky Mist Cheese $\left(6.0 \times 10^{4} \mathrm{CFU} / \mathrm{ml}\right)$ and Idly Batter $\left(1.5 \times 10^{4} \mathrm{CFU} / \mathrm{ml}\right)$.

According to Shannon et al., (2018), starter cultures were used in the production of cultured dairy products, cheese and fermented sausages to survive fermentation, the LAB and other microorganisms found in the finished product must deal with a variety of selective and competitive pressures such as salts, organic acids, ethanol, anaerobiosis and low $\mathrm{pH}$. Furthermore, the incubation temperature during growth and nutrient content were usually well-suited to the needs of microorganisms.

Campo et al., (2005) isolated Lactobacillus delbrueckii from yoghurt and found that the population count was $1.3 \times 10^{5} \mathrm{CFU} / \mathrm{g}$, The population count of Lactobacillus bulgaricus obtained from fermented beverages was $6.4 \mathrm{x}$ $10^{4} \mathrm{CFU} / \mathrm{ml}$ Thamer and Penna (2005) discovered a population of $L$. bulgaricus ranging from 7.3 to $11.4 \times 10^{4} \mathrm{CFU} / \mathrm{mL}$ in fermented milk beverages containing varying amounts of whey, sugar and fructo- 
oligosaccharides. Sivieri et al., (2011) stated that population of L. bulgaricus was slightly lower in the products with buttermilk addition, which could minimize the problem of excessive post-acidification during the product shelf life. Nivedita et al., (2014) reported that Lactobacillus fermentum $49 \times 10^{5} \mathrm{CFU} / \mathrm{g}$ was obtained from dough and Lactobacillus fermentum, Lactobacillus acidophilus $34 \times 10^{5}$ $\mathrm{CFU} / \mathrm{g}$ and $20 \times 10^{5} \mathrm{CFU} / \mathrm{g}$ respectively were obtained from Lassi.

\section{Morphological characteristics of the isolates}

Morphological characteristics were determined by culturing micro-organisms on MRS agar plates. The results pertaining to characteristics of colonies and gram's reaction discussed here under Table 4

Sixteen isolates were observed, isolated and characterized culturally and morphologically. The colour of the isolates differed. The LAB isolates took 48-72 hours to establish their growth on MRS agar medium. Of the 16 isolates, four isolates (SBM, SCU, JLS, SYD) were rod shaped, ten isolates (JBM, HCU, DB, ABM, IB, KM, MY, MZC, PY, SA) were oval shaped while one isolate (MMC) was chain shaped and one isolate (HP) was cocci shaped.

The colour of the isolates ranged from creamy white to white and thick white. Among sixteen isolates seven isolates (JBM, SBM, ABM, HP, $\mathrm{KM}$, JLS, SA) were white in colour, 4 isolates (HCU, SCU, DB, IB) were thick white in colour, five isolates (MY, PY, MZC, SYD, MMC) were creamy white in colour. Twelve isolates (JBM, HCU, DB, ABM, HP, IB, KM, MY, MZC, PY, SA, SYD) showed gram positive reaction and four isolates (SBM, SCU, JLS, MMC) showed gram negative reaction. $\mathrm{LAB}$ belong to a gram-positive bacteria that produce lactic acid as their main fermentation product into the culture medium and generally recognized as safe (Konings et al., 2000).

The present findings were in line with those of Kavitha and Jeevaratnam (2016) who reported that the isolates in the curd samples were both gram negative and positive and tentatively identified as Lactobacillus acidophilus, Lactobacillus bulgaricus, and Lactobacillus lactis like different species within the Lactobacillus genera.

Studies by Salvetti et al., (2012), Vyas et al., (2014) and Rao et al., (2015) identified and confirmed that Lactobacillus spp. were grampositive.

Misganaw and Teketay (2016) discovered that morphological LAB isolates from milk had chain, cocci, rod and ovoid shapes. Mannan et al., (2017) reported that 25 Lactobacillus strains from local fermented foods such as yoghurt and cheese were gram-positive and rod shaped.

\section{Biochemical characterization of Lactic Acid Bacteria isolates}

\section{Catalase test}

The catalase test was found to be positive for isolates such as SA, KM, SBM, MY, JBM, JLS, MZC, HCU, IB and DB. All the isolates produced gas bubbles. Presence of catalase enzyme within them caused the formation of gas bubbles. Similarly, Maragkoudakis et al., (2006), Kavitha et al., (2013) and Timothy et al., (2017) reported similar results for L. casei and L. rhamnosus obtained from traditionally fermented foods like curd and idly batter.

The catalase test was negative for ABM, HP, SCU, SYD, MMC and PY isolates. Because the bacteria was not able to produce the catalase enzyme which converts hydrogen peroxide into water and oxygen, no bubble 
was observed. Guessas et al., (2004) stated that Lactobacilli species found in local raw milk were $L b$. curvatus, Lb. helveticus, $L b$. plantarum, Lb. reuteri, Lb. casei, Lb. brevis, $L b$. bulgaricus, $L b$. paracasei and $L b$. acidophilus all of which showed catalase test to be negative.

Lactobacillus isolates from yoghurts, such as Lactobacillus delbrueckii ssp. bulgaricus, showed a catalase negative reaction in a study conducted by Mamata et al., (2017) Catalase negative reactions have previously been reported by Djide et al., (2008), Hawaz (2014), Ibrahim et al., (2015), Sarangdhar et al., (2015) and Saif et al., (2016) in fermented products such as curd, yoghurt and cheese.

\section{Oxidase test}

The bacterial cultures were unable to oxidize the colorless reagent, tetramethyl p-phenylene diamine dihydrochloride to produce the purple compound in the oxidase test. The isolates lacked cytochrome $\mathrm{C}$, which allows them to use free oxygen in their energy metabolism as stated by Mamata et al., (2017).

Positive oxidase test was seen in isolates such as SA, KM, MY, SCU, JBM, JLS, MZC, HCU, DB and IB. Souid et al., (2015) investigated that Lactococcus lactis from cheese that showed positive reaction in oxidase test. Ankur et al., (2017) reported Lactobacilli isolates from fermented dairy products showed positive reaction. Lactic acid bacteria showed a positive reaction in fermented milk as observed by Sawadogo et al., (2019).

Oxidase tests revealed negative results in isolates of SBM, HP, ABM, SYD, MMC, and PY. The present results were consistent with those of Ouoba et al., (2009) who discovered that LAB isolated from African traditional alkaline fermented foods were oxidase negative. According to Mamata et al., (2017) certain Lactobacillus isolates such as Lactobacillus delbrueckii ssp. Bulgaricus isolated from curd and probiotic beverages a negative oxidase reaction. Lactobacillus isolates demonstrated a negative reaction even in the studies conducted by Nazneen et al., (2015) and Saif et al., (2016).

\section{Methyl red test}

Methyl red test is based on the principle of fermentation of glucose to pyruvic acid and oxidation of pyruvic acid to other acids such as lactic, acetic and formic acids which results in decrease in $\mathrm{pH}$. The methyl red then turns red indicating a positive reaction.

The isolates such as SBM, HP, JBM, MZC, SYD, IB and DB tested positive for methyl red test. These results were in line with Kamel et al., (2012) who stated that lactic acid bacteria in fermented dairy products showed a positive reaction. Apoorva et al., (2013) reported that Lactobacillus. fermentum, $L$. brevis from dairy products (curd, buttermilk, paneer whey) and beverages exhibited positive reactions.

The isolates such as $\mathrm{SA}, \mathrm{KM}, \mathrm{ABM}, \mathrm{MY}$, SCU, JLS, MZC, HCU, MMC and PY tested negative for the methyl red test. The current results are in line with Jagadeeswari et al., (2010) who stated Lactobacillus isolated from traditional fermented foods like dosa batter, appam batter, buttermilk, yoghurt and cabbage exhibited negative reaction.

Kavitha et al., (2016) reported that Lactobacillus acidophilus from dahi sample showed negative reaction. Ankur et al., (2017) concluded that some isolates of LAB from fermented foods showed positive while some others showed negative reaction for methyl red test. Lactobacillus bulgaricus and Lactobacillus fermentum from curd and milk 
respectively showed negative reactions according to Timothy (2017). Another study conducted by Ngene et al., (2019) found that Lactococcus lactis, Lactobacillus brevis, Lactobacillus fermentum, Lactobacillus casei, Lactobacillus plantarum from yoghurt showed negative reaction.

\section{Gas formation from glucose}

The isolates such as KM, SBM, MY, HCU, IB and $\mathrm{DB}$ showed positive reaction for gas formation from glucose. Isolates such as $\mathrm{SA}$, ABM, HP, SCU, JBM, JLS, MZC, SYD, MMC and PY did not express formation of gas from glucose. They were negative.

The isolates could produce any gas as shown by a hollow space in the inverted Durham's tubes and therefore concluded as positive for gas production from glucose. Some of the isolates of LAB showed both positive and negative results for gas formation as per the study conducted by Monica et al., (2012). Lactobacillus brevis, Lactobacillus divergens, Lactobacillus fermentum, Lactobacillus buchneri, and Lactobacillus reuteri were found in dairy products and produced gas from glucose reported by Sheela et al., (2015).

Some LAB isolated from fermented products were shown to be positive and some were shown to be negative in gas formation from glucose in studies conducted by Kuikui (2015).

According to Bennani et al., (2017) Lactobacillus delbrueckii subsp. Bulgaricus, Lactobacillus delbrueckii subsp. Lactis, Lactobacillus delbrueckii subsp. and Lactobacillus plantarum were all homofermentative while Lactobacillus brevis was found to be heterofermentative for fermenting glucose.

\section{Arginine hydrolysis}

Isolates such as $\mathrm{SA}, \mathrm{KM}, \mathrm{ABM}, \mathrm{SBM}, \mathrm{MY}$, SCU, JBM, MZC, MMC, IB, and DB were showed positive reactions. Isolates such as HP, JLS, SYD, HCU, and PY isolates were negative.

The isolates produced yellow color in the arginine hydrolysis test, indicating that they cannot produce ammonia from arginine. The organisms could not use the amino acid arginine as a source of carbon and energy (Chris et al., 2006).

Tanasupawat et al., (2006) stated that LAB isolates from fermented sausages showed both negative and positive results. Pooja et al., (2015) reported that LAB isolate like $L$. fermentum, $L$. paracasei, $L$. amylophilus isolated from dairy and non-dairy fermented products like curd, dosa batter and fermented cabbage showed both positive and negative results.

Rhaiem et al., (2016) reported that LAB isolates Lactobacillus plantarum and Lactobacillus delbruecki did not produce ammonia from arginine, whereas one isolate of Lactobacillus fermentum did produce ammonia from arginine. Another study conducted by Sneha et al., (2017) reported that LAB strains from curd and fruit juice showed both positive and negative results.

\section{Aescualin fermentation}

The Aescualin fermentation test showed positive reaction in isolates such as $\mathrm{SA}, \mathrm{KM}$, ABM, SBM, MY, SCU, JBM and MZC. These isolates had ability to hydrolyze glycoside aesculin to aesculetin and glucose. The isolates such as MMC, IB, DB, HP, JLS, SYD, HCU and PY showed negative reaction. 
Table.1 Collection of fermented food samples from commercial sources

\begin{tabular}{|c|c|c|c|}
\hline S.No & Food sample & Code & Source \\
\hline $\mathbf{1 .}$ & Buttermilk (Amul) & ABM & Reliance super market, Guntur \\
\hline $\mathbf{2 .}$ & Buttermilk (Jersey) & JBM & Reliance super market, Guntur \\
\hline $\mathbf{3 .}$ & Butter milk (Sangam) & SBM & Reliance super market, Guntur \\
\hline $\mathbf{4 .}$ & Blue berry yoghurt & BBY & Vijetha super market, Guntur \\
\hline $\mathbf{5 .}$ & Cheese (Amul) & AMC & Spencer's super market, Guntur \\
\hline $\mathbf{6 .}$ & Cheese (Milky mist) & MMC & D- mart super market, Guntur \\
\hline $\mathbf{7 .}$ & Curd (Sangam) & SCU & Local super market, Guntur \\
\hline $\mathbf{8 .}$ & Greek Yoghurt & GY & Vijetha super market, Guntur \\
\hline $\mathbf{9 .}$ & Health potion drink & HP & Online stores \\
\hline $\mathbf{1 0 .}$ & Kombucha & KM & Online stores \\
\hline $\mathbf{1 1 .}$ & Lassi (Britania) & BLS & Reliance super market, Guntur \\
\hline $\mathbf{1 2 .}$ & Lassi (Jersey) & JLS & Reliance super market, Guntur \\
\hline $\mathbf{1 3 .}$ & Lassi (Amul) & ALS & Reliance super market, Guntur \\
\hline $\mathbf{1 4 .}$ & Mango yoghurt & MY & Super market, Guntur \\
\hline $\mathbf{1 5 .}$ & Mozzarella Cheese & MZC & Heritage, Guntur \\
\hline $\mathbf{1 6 .}$ & Mango yoghurt drink & MYD & Spencer's super market, Guntur \\
\hline $\mathbf{1 7 .}$ & Misti Doi & MD & Vijetha super market, Guntur \\
\hline $\mathbf{1 8 .}$ & Probiotic milk drink & PML & Vijetha super market, Guntur \\
\hline $\mathbf{1 9 .}$ & Peach yoghurt & PY & D-mart super market, Vijayawada \\
\hline $\mathbf{2 0 .}$ & Raspberry Yoghurt & RY & Local super market, Guntur \\
\hline $\mathbf{2 1 .}$ & Sauerkraut & SA & Online stores \\
\hline $\mathbf{2 2 .}$ & Straw berry yoghurt & SYD & Heritage, Vijayawada \\
\hline $\mathbf{2 3 .}$ & Straw berry yoghurt & SY & Heritage, Vijayawada \\
\hline & & & \\
\hline
\end{tabular}

Table. 2 Collection of fermented food samples from house holds

\begin{tabular}{|c|c|c|c|}
\hline S. No. & Food sample & Code & Source \\
\hline $\mathbf{1 .}$ & Curd (Homemade) & HCU & House hold, Guntur \\
\hline $\mathbf{2 .}$ & Dosa & DA & House hold, Guntur \\
\hline $\mathbf{3 .}$ & Dosa batter & DB & House hold, Guntur \\
\hline $\mathbf{4 .}$ & Fermented grape juice & FGJ & House hold, Guntur \\
\hline $\mathbf{5 .}$ & Idly & ID & House hold, Guntur \\
\hline $\mathbf{6 .}$ & Idly batter & IB & House hold, Guntur \\
\hline $\mathbf{7 .}$ & Punugu & PN & House hold, Guntur \\
\hline
\end{tabular}


Table.3 Isolation and population count of LAB

\begin{tabular}{|c|c|c|c|}
\hline S. No & Code & $\begin{array}{c}\text { No. of isolates } \\
\text { obtained }\end{array}$ & $\begin{array}{c}\text { Lactic acid bacteria population } \\
\text { (CFU/ml) }\end{array}$ \\
\hline $\mathbf{1 .}$ & JBM & 1 & $10 \times 10^{4}$ \\
\hline $\mathbf{2 .}$ & SBM & 1 & $2.6 \times 10^{4}$ \\
\hline $\mathbf{3 .}$ & HCU & 1 & $4.0 \times 10^{4}$ \\
\hline $\mathbf{4 .}$ & SCU & 1 & $5.5 \times 10^{4}$ \\
\hline $\mathbf{5 .}$ & DB & 1 & $5.0 \times 10^{4}$ \\
\hline $\mathbf{6 .}$ & ABM & 1 & $9.8 \times 10^{4}$ \\
\hline $\mathbf{7 .}$ & HP & 1 & $7.2 \times 10^{4}$ \\
\hline $\mathbf{8 .}$ & IB & 1 & $1.5 \times 10^{4}$ \\
\hline $\mathbf{9 .}$ & KM & 1 & $8.8 \times 10^{4}$ \\
\hline $\mathbf{1 0 .}$ & JLS & 1 & $2.0 \times 10^{4}$ \\
\hline $\mathbf{1 1 .}$ & MY & 1 & $4.0 \times 10^{4}$ \\
\hline $\mathbf{1 2 .}$ & MZC & 1 & $6.0 \times 10^{4}$ \\
\hline $\mathbf{1 3 .}$ & PY & 1 & $1.6 \times 10^{4}$ \\
\hline $\mathbf{1 4 .}$ & SA & 1 & $2.5 \times 10^{4}$ \\
\hline $\mathbf{1 5 .}$ & SYD & 1 & $2.4 \times 10^{4}$ \\
\hline $\mathbf{1 6 .}$ & MMC & 1 & $6.0 \times 10^{4}$ \\
\hline
\end{tabular}

Table.4 Characteristics of colonies and Gram's reaction

\begin{tabular}{|c|c|c|c|c|}
\hline \multirow{2}{*}{ S. No. } & \multirow{2}{*}{ Code } & \multicolumn{2}{|c|}{ Colony characteristics } & Gram's reaction \\
\cline { 3 - 5 } & & Colour & Shape & $\begin{array}{c}\text { +ve/-ve } \\
\text { +ve }\end{array}$ \\
\hline $\mathbf{1 .}$ & JBM & White & Oval & -ve \\
\hline $\mathbf{2 .}$ & SBM & White & Rod & +ve \\
\hline $\mathbf{3 .}$ & HCU & Thick white & Oval & -ve \\
\hline $\mathbf{4 .}$ & SCU & Thick white & Rod & +ve \\
\hline $\mathbf{5 .}$ & DB & Thick white & Oval & +ve \\
\hline $\mathbf{6 .}$ & ABM & White & Oval & +ve \\
\hline $\mathbf{7 .}$ & HP & White & Cocci & +ve \\
\hline $\mathbf{8 .}$ & IB & Thick white & Oval & +ve \\
\hline $\mathbf{9 .}$ & KM & White & Oval & -ve \\
\hline $\mathbf{1 0 .}$ & JLS & White & Rod & +ve \\
\hline $\mathbf{1 1 .}$ & MY & Creamy white & Oval & +ve \\
\hline $\mathbf{1 2 .}$ & MZC & Creamy white & Oval & +ve \\
\hline $\mathbf{1 3 .}$ & PY & Creamy white & Oval & +ve \\
\hline $\mathbf{1 4 .}$ & SA & White & Oval & +ve \\
\hline $\mathbf{1 5 .}$ & SYD & Creamy white & Rod & -ve \\
\hline $\mathbf{1 6 .}$ & MMC & Creamy white & Chain & \\
\hline
\end{tabular}


Table.5 Bio chemical characterization of isolates

\begin{tabular}{|c|c|c|c|c|c|c|c|c|c|c|}
\hline \multirow[b]{2}{*}{ Isolate } & \multicolumn{10}{|c|}{ Biochemical tests } \\
\hline & $\begin{array}{c}\text { Catalase } \\
\text { test }\end{array}$ & $\begin{array}{c}\text { Oxidas } \\
\text { e test }\end{array}$ & $\begin{array}{l}\text { Methyl } \\
\text { red test }\end{array}$ & $\begin{array}{c}\text { Gas } \\
\text { formation } \\
\text { from } \\
\text { Glucose }\end{array}$ & $\begin{array}{c}\text { Arginine } \\
\text { hydrolysis } \\
\text { test }\end{array}$ & $\begin{array}{c}\text { Aescualin } \\
\text { fermentatio } \\
n \text { test }\end{array}$ & $\begin{array}{c}\text { Nitrate } \\
\text { reductase } \\
\text { test }\end{array}$ & $\begin{array}{c}\text { Citrate } \\
\text { utilization } \\
\text { test }\end{array}$ & $\begin{array}{c}\text { Starch } \\
\text { hydrolysis } \\
\text { test }\end{array}$ & $\begin{array}{c}\text { Voges } \\
\text { Prausker' } \\
\text { s test }\end{array}$ \\
\hline JBM & + & + & + & - & + & + & + & - & - & - \\
\hline SBM & + & - & + & + & + & + & + & - & - & + \\
\hline HCU & + & + & - & + & - & - & - & - & - & - \\
\hline SCU & - & + & - & - & + & + & - & - & - & + \\
\hline DB & + & + & + & + & + & - & - & - & - & - \\
\hline ABM & - & - & - & - & + & + & - & - & - & - \\
\hline HP & - & - & + & - & - & - & + & + & - & - \\
\hline IB & + & + & + & + & + & - & - & + & - & + \\
\hline KM & + & + & - & + & + & + & + & - & - & - \\
\hline JLS & + & + & - & - & - & - & + & - & + & + \\
\hline MY & + & + & - & + & + & + & - & - & - & - \\
\hline MZC & + & + & + & - & + & + & + & + & - & - \\
\hline PY & - & - & - & - & - & - & + & + & - & - \\
\hline SA & + & + & - & - & + & + & + & - & - & - \\
\hline SYD & - & - & + & - & - & - & - & - & + & - \\
\hline MMC & - & - & - & - & + & - & + & - & - & + \\
\hline
\end{tabular}


The present findings were similar with those of Jamuna and Jeevaratnam (2004) who stated that $\mathrm{LAB}$ isolated from fermented foods like appam batter and pickles showed negative and positive results for Aescualin fermentation. Tanasupawat et al., (2006) reported that some of the LAB isolates from traditional Thai fermented sausages were positive and some were negative for Aescualin fermentation. Similar results were obtained by Ashmaig et al., (2009) who stated that LAB isolate from traditional Sudanese fermented milk showed positive and negative results.

Sneha et al., (2017) found that LAB strains from curd and juiceof fruit showed both positive and negative results. Bennani et al., (2017) concluded that isolates of LAB from cow milk showed both negative and positive reactions for Aescualin fermentation.

\section{Nitrate reductase test}

In the nitrate reductase test, presence of the nitrate enzyme, the test reagent $\mathrm{KNO} 3$ is converted to $\mathrm{NO}_{2}$, which reacts with the indicator sulphanilic acid and naphthylamine to form nitrous derivatives with a characteristic red color.

The isolates such as SA, KM, SBM, HP, JBM, JLS, MZC, MMC, and PY showed positive reactions for nitrate reductase test. These results were similar to the results of Monica $e t$ al., (2012) who investigated that LAB isolates from some fermented foods showed s positive while some showed negative results. Zakpaa et al., (2009) reported that only one LAB isolate from fermented foods like fermented meat products showed a positive result and only one isolate showed a negative result.

The isolates such as ABM, MY, SCU, SYD, $\mathrm{HCU}, \mathrm{IB}$, and DB were all negative. Kavitha et al., (2016) reported that Lactobacillus acidophilus from dahi samples showed a negative reaction. The results of the present study were in line with those of Sneha et al., (2017) who reported negative results for LAB from curd and fruit juice.

\section{Citrate utilization test}

The positive results were showed for HP, MZC, PY and IB while negative results were obtained for SA, KM, SBM, ABM, MY, SCU, JBM, JLS, SYD, HCU, MMC and DB for citrate utilization test. Monica et al., (2012) and Mamata et al., (2017) reported that some of lactic acid bacteria isolates from non-dairy probiotic drinks showed positive and some showed negative.

The present findings were similar to the findings of Ankita and Jayanti (2015) who reported that the probiotic properties of Lactobacillus Spp. from selected regional dairy products showed negative citrate utilization test. Kavitha et al., (2016) found that Lactobacillus acidophilus from a dahi sample showed a negative reaction. Ankur et al., (2017) stated that lactic acid bacteria isolated from fermented foods were negative for citrate utilization. Timothy (2017) reported that Lactobacillus fermentum and Lactobacillus bulgaricus from curd and milk showed negative reactions.

\section{Starch hydrolysis}

Determination of amylase production potentials of LAB isolates was carried out using starch hydrolysis test procedures adapted by Sun et al., 2010.

The isolates such as HP, MZC, PY, IB, SA, $\mathrm{KM}$, SBM, ABM, MY, SCU, JBM, HCU, MMC, DB isolates showed negative results. JLS and SYD isolates showed positive results in starch hydrolysis test. The present findings were in line with those of Abhijit et al., (2012), who reported that lactobacillus strains 
obtained from pickled vegetables and fermented beverages showed a positive reaction.

Ankita and Jayanti (2018) reported that the probiotic properties of Lactobacillus Spp. from selected regional dairy products showed negative results in starch hydrolysis tests. Timothy et al., (2017) determined the amylase production of LAB isolates from curd and milk. Isolates of LAB showed that some positive and negative results in starch hydrolysis test.

\section{Voges Prausker's test}

The VP test is used to determine if an organism produces acetyl methyl carbinol from glucose fermentation. If present, acetyl methyl carbinol is converted to diacetyl in the presence of alpha-naphthol, strong alkali and atmospheric oxygen.

The isolates such as SBM, SCU, JLS, MMC, IB tested positive. Isolates such as SYD, HP, MZC, PY, KM, ABM, MY, JBM, HCU, MMC, DB showed negative reaction in Voges Prausker's test. These results were in line with those of Sung Mee et al., (2008) who stated that $L$. plantarum from kimchi fermented products showed a negative reaction.

The common characters of Lactobacillus species showed negative in Voges Prausker's test reaction conducted by Guessas and Kihal (2004). Hossain et al., (2010) reported that Lactobacillus isolates from yoghurt showed a negative reaction. The present study results are similar to those of Rhaiem et al., (2016) who reported the absence of colour changes occurring in LAB strains of the Voges Proskauer test. Another study conducted by Arindam and Chandan (2017) reported that some LAB isolates were positive and some isolates showed negative reaction. Ngene et al., (2017) stated that Lactococcus lactis,
Lactobacillus brevis, Lactobacillus fermentum, Lactobacillus casei, and Lactobacillus plantarum strains from yoghurt showed negative reactions for Voges Prausker's test.

In present investigation, thirty bacterial isolates were collected from both dairy and non-dairy samples. All the isolates were characterized on the basis of colony morphology and biochemical characteristics. Sixteen bacterial isolates were identified as Lactobacillus by morphological, cultural and biochemical characteristics. Further study of selected Lactobacillus isolates by $16 \mathrm{~S}$ rDNA gene sequencing is being undertaken for its species identification.

\section{References}

Abbas, A., Rizvi, F., Hussain, S., Ali, S., Rafique, R., Manzoor, A. W.,.. \& Shaukat, H. (2021). Immuno-modulatory effects of Lactobacillus in Salmonella gallinarum infected broiler chicks. Pakistan Journal of Science, 73(1).

Abou Ayana, I. A. A., \& Ibrahim, A. E. (2015). Attributes of low-fat yogurt and Kareish cheese made using exopolysaccharides producing lactic acid bacteria. Am J Food Tech, 10(48), 57.

Ananou, S., Maqueda, M., Martínez-Bueno, M., \& Valdivia, E. (2007). Bio preservation, an ecological approach to improve the safety and shelf-life of foods. Communicating current research and educational topics and trends in applied microbiology, 1, 475-487.

Ansorena, D., and I. Astiasaran. 2016. Fermented foods: Composition and health effects encyclopaedia of food and health (pp. 649-55). Oxford: Academic press.

Ashmaig, A., Hasan, A., \& El Gaali, E. (2009). Identification of lactic acid bacteria isolated from traditional 
Sudanese fermented camel's milk (Gariss). African Journal of Microbiology Research, 3(8), 451-457.

Awan, J. A. and S. U. Rahman, 2005. Microbiology Manual. Unitech Communications, Faisalabad, Pakistan, pp: 49-51.

Bansal, S., Singh, A., Mangal, M., \& Sharma, S. K. (2013). Isolation and characterization of lactic acid bacteria from fermented foods. Vegetos, 26(2), 325-330.

Bennani, S., Mchiouer, K., Rokni, Y., \& Meziane, M. (2017). Characterization and identification of lactic acid bacteria isolated from Moroccan raw cow's milk. Journal of Material and Environmental Sciences, 8, 4934-4944.

Bhardwaj, A., Puniya, M., Sangu, K. P. S., Kumar, S., \& Dhewa, T. (2012). Isolation and biochemical characterization of Lactobacillus species isolated from Dahi. Research \& Reviews: A Journal of Dairy Science and Technology, 1, 18-31.

Bomba, A., Nemcova, R., Macronova, D., \& Guba, P. (2002). The possibilities of potentiating the efficacy of probiotics. Trends in Food Science \& Technology, 13(4), 121-126.

Chatterjee, A., \& Abraham, J. (2018). Microbial contamination, prevention, and early detection in food industry. In Microbial Contamination and Food Degradation (pp. 21-47). Academic Press.

Chen, X., Du, X., Wang, W., Zhang, J., Sun, Z., Liu, W.,... \& Zhang, H. (2010). Isolation and identification of cultivable lactic acid bacteria in traditional fermented milk of Tibet in China. International journal of dairy technology, 63(3), 437-444.

Chris, B., N. Paul, and Anthony, P. W. 2006. Food Microbiology and Laboratory Practices. Blackwell Publishing, State
Avenue, USA.

Cisse, H., Kagambèga, B., Sawadogo, A., Tankoano, A., Sangaré, G., Traoré, Y.,... \& Savadogo, A. (2019). Molecular characterization of Bacillus, lactic acid bacteria and yeast as potential probiotic isolated from fermented food. Scientific African, 6, e00175.

Crown ST, Gen J (1998) Micro method for the methyl red test Microbiology. 9:101-109

De Bassi, L. G., Ferreira, G. C. C., Da Silva, A. S., Sivieri, K., Aragon-Alegro, L. C., \& Costa, M. D. R. (2012). Evaluation of physicochemical, microbiological and sensorial characteristics of fermented milk beverages with buttermilk addition. International journal of dairy technology, 65(2), 282-286.

Del Campo, R., Bravo, D., Canton, R., RuizGarbajosa, P., García-Albiach, R., Montesi-Libois, A.,... \& Baquero, F. (2005). Scarce evidence of yogurt lactic acid bacteria in human feces after daily yogurt consumption by healthy volunteers. Applied and Environmental Microbiology, 71(1), 547-549.

De Vuyst, L., \& Leroy, F. (2007). Bacteriocins from lactic acid bacteria: production, purification, and food applications. Journal of molecular microbiology and biotechnology, 13(4), 194-199.

Djide M N, and Wahyuddin, E (2008) Isolasi Bakteri Asam Laktat dan Air Susu Ibu dan Potensinya dalam Penurunan Kadar Cholesterol Secara In Vitro. Majalah Farmasi dan Farmakologi. 12 (3): 12-15.

Gautam N, Sharma N (2014) Quality attributes of novel cereal based probiotic products prepared by using food grade lactic acid bacteria. Indian $\mathrm{J}$ Tradit Know 13: 525-530.

Giraffa, G., Chanishvili, N., \& Widyastuti, Y. (2010). Importance of lactobacilli in food and feed biotechnology. Research in microbiology, 161(6), 480-487. 
Guarner, F., \& Malagelada, J. R. (2003). Gut flora in health and disease. The Lancet, 361(9356), 512-519.

Guessas, B., \& Kihal, M. (2004). Characterization of lactic acid bacteria isolated from Algerian arid zone raw goatsl'milk. African Journal of Biotechnology, 3(6), 339-342.

Hawaz, E. (2014). A review on lactic acid bacteria in indigenous traditionally fermented camel milk of Ethiopia. Int. J. Microbio. Research and Reviews, 3, 122-126.

Hoque, M. Z., Akter, F., Hossain, K. M., Rahman, M. S. M., Billah, M. M., \& Islam, K. M. D. (2010). Isolation, identification and analysis of probiotic properties of Lactobacillus spp. from selective regional yoghurts. World $J$ Dairy Food Sci, 5(1), 39-46.

Jagadeeswari, S., Vidya, P., Kumar, D. M., \& Balakumaran, M. D. (2010). Isolation and characterization of bacteriocin producing lactobacillus sp. from traditional fermented foods. Electronic Journal of Environmental Agricultural and Food Chemistry, 9(3), 575-581.

Kamrun N L, Touaha A, Fahmida A, Nazeen $\mathrm{N}$ L. Characterization and confirmation of Lactobacillus spp. from selective regional yoghurts for probiotic and interference with pathogenic bacterial growth. Asian journal of biological sciences. 2016;9: 1-9.

Kavitha, S., Jayashree, C., Kumar, S., Yeom, I., Banu, J., 2013. Effect of enzyme secreting bacterial pretreatment on enhancement of aerobic digestion potential of waste activated sludge interceded through EDTA. Bioresource Technology 150, 210 -219

Kavitha, S., \& Jeevaratnam, K. (2016). Molecular characterization of lactobacilli isolated from Piper betle L. var. Pachaikodi and Comparative analysis of the antimicrobial effects of isolate
Lactobacillus plantarum KJB23 and betel leaves extract. Food Biotechnology, 30(2), 123-136.

Konings, W. N., Kok, J., Kuipers, O. P., \& Poolman, B. (2000). Lactic acid bacteria: the bugs of the new millennium. Current opinion in microbiology, 3(3), 276-282.

K. R. Aneja, Experiments in Microbiology Plant Pathology and Biotechnology, 4th edition, New Age International Publishers, New Delhi, India, 2003.

Mac Faddin, J. F. (2000): Biochemical tests for identification of medical bacteria. 3rd ed. Lippincott Williams and Wilkins, Washington, Philadelphia, U.S.A

Mannan, S. J., Rezwan, R., Rahman, M. S., \& Begum, K. (2017). Isolation and biochemical characterization of Lactobacillus species from yogurt and cheese samples in Dhaka metropolitan area. Bangladesh Pharmaceutical Journal, 20(1), 27-33.

Maragkoudakis P A, Zoumpopoulou G, Miaris C, Kalantzopoulos G, Pot B, Tsakalidou E (2006) Probiotic potential of Lactobacillus strains isolated from dairy products. Int Dairy J 16:189-199

Mathew, S., Vijay, S., \& Potty, V. P. (2017). Assessment of probiotic potential of lactic acid bacteria isolated from curd and its application using fruit juice. Int $J$ Curr Microbiol Appl Scie, 6, 282-289.

Mithun, S., Dipak, V., \& Sheela, S. (2015). Screening and characterization of novel bacteriocin producing lactobacilli obtained from raw milk samples. World Journal of Pharmaceutical Research, 4(4), 1976-1989.

Ngene, A. C., Onwuakor, C. E., Aguiyi, J. C., Ifeanyi, V. O., Ohaegbu, C. G., Okwuchukwu, C. P.,... \& Egbere, J. O. (2019). Screening of Some Lactic Acid Bacteria Isolated from Selected Nigerian Fermented Foods for Vitamin Production. Advances in Microbiology, 9(11), 943-955. 
Niccolai, A., Shannon, E., Abu-Ghannam, N., Biondi, N., Rodolfi, L., \& Tredici, M. R. (2019). Lactic acid fermentation of Arthrospira platensis (spirulina) biomass for probiotic-based products. Journal of Applied Phycology, 31(2), 1077-1083.

Ni, K., Wang, Y., Cai, Y., \& Pang, H. (2015). Natural lactic acid bacteria population and silage fermentation of whole-crop wheat. Asian-Australasian Journal of Animal Sciences, 28(8), 1123.

Nout, M. J. R. 2014. Food technologies: Fermentation A2- Motarjemi, Yasmine Encyclopaedia of food safety (pp. 168177). Waltham Academic press.

Pelinescu, D. R., E. Sasarmaan, M. C. Chifiriuc, I. Staca, A. M. Nohita, I. Avram, F. Serbancea, and Dimov, T. V. 2009. Isolation and identification of some Lactobacillus and Enterococcus by a polyphasic taxonomical approach. Romaniun Biotechnol. Lett., 14: 42254233.

Phalakornkule, C., \& Tanasupawat, S. (2006). Characterization of lactic acid bacteria from traditional Thai fermented sausages.

Pooja, T., Modi, H. A. and Prajapati, J. B. 2015. Isolation, characterization and safety assessment of lactic acid bacterial isolates from fermented food products. International journal of Current Microbiology and Applied Sciences. 4(4), 713-725.

Rangaswami, G. and Bagayaraj, D. J. 1993. Microbial Biotechnology. In: Agricultural Microbiology. Prentice Hall of India Pvt. Ltd., New Delhi. 389-405 PP.

Rao, K. P., Chennappa, G., Suraj, U., Nagaraja, H., Raj, A. P. C. and Sreenivasa, M. Y. 2015. Probiotic potential of Lactobacillus strains isolated from Sorghum-based traditional fermented food. Probiotics and Antimicro. Prot. 7, 146-156
Rhaiem, N., Chahboun, N., Inekach, S., \& Ouhssine, M. (2016). Identification and characterization of lactic acid bacteria isolated from cow milk and olives brine. Journal Material Environment Science, 7(5), 1504-1509.

Roy, A., \& Rai, C. (2017). Isolation and characterization of lactic acid bacteria with probiotic potential from pickles. Bioscience Discovery, 8(4), 866-875.

Ruethaiwan S, Chanthachum S, Sumpavapol P. 2012. Screening and identification of probiotic lactic acid bacteria isolated from Poo-Khem, a traditional salted crab. International Conference on Nutrition and Food Sciences IPCBEE. Singapore: IACSIT Press.

Saif, F. A. A. A. (2016). Efficacy of Lactic Acid Bacteria isolated from some fruits and vegetables. Egyptian Journal of Microbiology, 51(1), 13-28.

Salvetti, E., Torriani, S. and Felis, G. E. 2012. The genus Lactobacillus: a taxonomic update. Probiotics \& Antimicro. Prot. 4, 217-226. DOI 10.1007/s12602-0129117-8

Sanlier, N., Gokcen, B. B., \& Sezgin, A. C. 2019. Health benefits of fermented foods. Critical reviews in food science and nutrition, 59(3), 506-527.

Schrezenmeir, J., \& de Verse, M. (2001). Probiotics, prebiotics, and synbioticsapproaching a definition. The American journal of clinical nutrition, 73(2), 361s$364 \mathrm{~s}$.

Secchi, N., Giunta, D., Pretti, L., García, M. R., Roggio, T., Mannazzu, I., \& Catzeddu, P. (2012). Bioconversion of ovine scotta into lactic acid with pure and mixed cultures of lactic acid bacteria. Journal of Industrial Microbiology and Biotechnology, 39(1), 175-181.

Shruthy V, Pavithra M. Ghose Asit. (2011). Probiotic potential among lactic acid bacteria isolated from curd. IJRAP, 2 
(2), pp. 602-609.

Sieladie, D. V., Zambou, N. F., Kaktcham, P. M., Cresci, A., \& Fonteh, F. 2011. Probiotic properties of lactobacilli strains isolated from raw cow milk in the western highlands of Cameroon. Innovative Romanian Food Biotechnology, (9).

Soccol, C. R., Vandenberghe, L. P. D. S., Spier, M. R., Medeiros, A. B. P., Yamaguishi, C. T., Lindner, J. D. D. \& Thomas-Soccol, V. (2010). The potential of probiotics: a review. Food Technology and Biotechnology, 48(4), 413-434.

Souid, W., Boudjenah-Haroun, S., Siboukeur, O. E. K., \& Mati, A. (2015). Potential use of the nisin produced by lactic acid bacteria for longer conservation of Camel cheese. Emirates Journal of Food and Agriculture, 784-789.

Thakur, M., Deshpande, H. W., \& Bhate, M. A. (2017). Isolation and identification of lactic acid bacteria and their exploration in non-dairy probiotic drink. Int. J. Curr. Microbiol. Appl. Sci, 6, 1023-1030.

Thamer, K. G., \& Penna, A. L. B. (2005). Effect of whey, sugar and fructooligosaccharides on the probiotic lactic acid bacteria population in fermented beverages. Revista Brasileira de Ciencias Pharmaceutica's, 41(3), 393400.

Thummar, A. C., \& Ramani, V. M. (2017). Characterization of $\alpha$-galactosidase Activity of Probiotics Lactic Acid
Bacteria.

Uaboi-Egbenni, P. O., Okolie, P. N., Sobande, A. O., Alao, O., Teniola, O., \& Bessong, P. O. (2009). Identification of subdominant lactic acid bacteria in dawadawa (a soup condiment) and their evolution during laboratory-scale fermentation of Parkia biglobosa (African locust beans). African Journal of Biotechnology, 8(25).

Van Hylckama Vlieg, J. E., Veiga, P., Zhang, C., Derrien, M., \& Zhao, L. (2011). Impact of microbial transformation of food on health - from fermented foods to fermentation in the gastro-intestinal tract. Current opinion in biotechnology, 22(2), 211-219.

Vantsawa, P. A., Maryah, U. T. and Timothy, B. (2017) Isolation and Identification of Lactic Acid Bacteria with Probiotic Potential from Fermented Cow Milk (Nono) in Unguwar Rimi Kaduna State Nigeria. American Journal of Molecular Biology, 7, 99-106.

Wassie, M., \& Wassie, T. (2016). Isolation and identification of lactic acid bacteria from raw cow milk. Int $\mathbf{J}$ Adv Res Biol Sci, 3(8), 44-49.

Zakpaa, H. D., Imbeah, C. M., \& MakMensah, E. E. (2009). Microbial characterization of fermented meat products in some selected markets in the Kumasi metropolis, Ghana. African Journal of Food Science, 3(11), 340346.

\section{How to cite this article:}

Sirisha, A., J. Lakshmi, K. Lakshmi and Vijaya Gopal, A. 2021. Isolation and Biochemical Characterization of Lactic Acid Bacteria from Fermented Foods. Int.J.Curr.Microbiol.App.Sci. 10(10): 584-600. doi: https://doi.org/10.20546/ijcmas.2021.1010.069 